\title{
LEVEL OF PRO-HEALTH BEHAVIOR OF WOMEN FROM RURAL AND METROPOLITAN ENVIRONMENT WHO ARE ACTIVE ON THE HEALTH-RELATED INTERNET PORTALS
}

\author{
Paweł F. Nowak, Zbigniew Borysiuk
}

Opole University of Technology

Nowak P.F., Borysiuk Z., (2014) Level of pro-health behavior of women from rural and metropolitan environment who are active on the health-related internet portals. Health Problems of Civilization 3 (8), p. 39-43

\begin{abstract}
Summary: The development of health education, education in the scope of healthy lifestyles is significantly affected by the mass media, and primarily the Internet, which is an interactive source of information and the space to acquire competencies supporting health. Access to the Internet is getting more and more widespread; also the range of easily accessible content, related to the lifestyle has expanded. Migrations of populations tend to impair the traditionally understood image of the urban and rural environments. Technological advances in the field of transport communications and IT have also reduced the distance between the two discussed environments. The aim of this study was to assess the level of pro-health behaviors of women who are interested in a healthy lifestyle, and who live both in the countryside and in large cities. The study involved 78 women from the towns with up to 3 thousand inhabitants and 130 from the cities with a population over 100 thousand inhabitants. All research participants were active participants in one of the largest health services for mature women in Poland. The research was part of the PARP project - Global health problems, implemented by the Foundation 'Smak Życia'. Standardized research tools Health Behavior Inventory were applied according to the adaptation of Z. Juczyński.

As many as $30 \%$ of patients achieved a low level of pro-health behaviors, $45 \%$ obtained an average score, and only $25 \%$-a high one, which due to an interest in the subject of a healthy lifestyle, occurring as a constant activity on the online health portal, can be regarded as an unsatisfactory result. The research participants (female subscribers of advice from pro-health service) willing to share their experience, commented on a variety of content related to health issues, however, the level of their health behaviors did not differ significantly from the average values for the Polish population. There was no statistically significant difference in the level of realized health behaviors between women living in rural and metropolitan environments. Research confirmed that Internet theme services concerning issues of a healthy lifestyle, are a chance to equalize disparities in pro-health behaviors, and consequently - in health itself, thus initiatives of raising interest in health education through the mass media ought to be supported.
\end{abstract}

Key words: health behaviors, health promotion, women, Internet, living environment

\section{Introduction}

There are many factors influencing the potential for human health. It is extremely difficult to identify them, and even more so to measure them. However, over the last several dozen years, many researchers have tried to achieve it given the increasing importance of this knowledge from the point of view of public health. Many models of the determinants of health (which were repeatedly publically presented since the 70s of the last century) assumed that it is the health behaviors which play a key role in preserving, restoring and creating human health (Woynarowska 2008).

Health understood in modern terms assumes its holistic perception, including also the adoption of individual responsibility for its condition. Thus, a healthy lifestyle has become one of the socially desirable values, determining social development, since numerous scientific studies confirm the link of one's lifestyle with all the dimensions of health (Pisinger et al. 2009). A healthy lifestyle is a category of individual choices, certain decisions, resulting in specific behaviors. Of course, there are also many limitations associated with the choice. Socio-economic barriers, social inequalities are often raised as those that contribute to inequalities in health, which is an important issue, and at the same time an objective, raised by the WHO in a report Health for everybody in the twenty-first century (Zdrowie 21, 2001).

Also in Poland a repeatedly amended National Health Programme has been already approved in Poland (2007, p. 15), in accordance with which the main target assumed an improvement of health and quality of life related to it and reducing inequalities with regards to health within the population.

Address for correspondence: Paweł F. Nowak, Opole University of Technology, Prószkowska 76 St., 45-758 Opole, e-mail: p.nowak@po.opole.pl, phone:697-719-604

Tables: 1, Figures: 2, References: 19, Full text PDF www.hpc.edu.pl Copyright (C) Pope John Paul II State School of Higher Education in Biała Podlaska, Sidorska 95/97, 21-500 Biała Podlaska Indexation: Index Copernicus, Database AGRO, ProQuest, Polish Ministry of Science and Higher Education. This is an open-access article distributed under the terms of the Creative Commons Attribution Non-commercial License (http://creativecommons.org/licenses/by-nc/3.0), which permits use, distribution, and reproduction in any medium, provided the original work is properly cited, the use is non-commercial and is otherwise in compliance with the license. 
Pro-health behaviors are those that in the light of modern medical knowledge usually evoke certain (positive or negative) health effects (Gniazdowski 1990, p. 1-2).

Despite the dynamic development of modern technologies in medicine, today the important role of individual health behaviors as necessary assistance in the modern health care system in which preventive measures are as important as corrective ones is indicated (Prochaska 2008). The desire to change health behaviors by eliminating or correcting negative habits, and at the same time developing skills and attitudes towards healthy behavior seems to be crucial in the context of the development of civilization diseases which are often based on specific patterns of behavior. It is therefore worth it to analyze health behavior of different social groups, coming from different backgrounds, in order to implement effective interventions of systemic nature. The aim of this study was to assess the level of health behaviors of women who are interested in a healthy lifestyle, living in rural environment, as well as in a large city.

\section{Material and method}

The study involved 78 women from the towns with up to 3 thousand inhabitants and 130 from the cities with a population over 100 thousand inhabitants. All the researched persons were active participants in one of the largest health services for mature women- menopauza.pl. The research was part of the project by PARP - Global health problems implemented by the Foundation 'Smak Życia'. Selection of the sample was purposeful, the study was conducted via the Internet (online questionnaire) by sending an invitation to participate in it only to persons subscribed to the newsletter of the above mentioned website.

To assess the level of health behaviors standardized research tool - Behavioral Health Inventory according to the adaptation of Juczyński (2009) was applied. This self-report questionnaire consisting of 24 statements describing various types of health behaviors, to which the test participant assigns values from 1 to 5 , with reference to the frequency of their occurrence. After summing up the values of all the statements the overall severity of health behavior was obtained, which is in the range from 24 to 120 points. The higher the ratio the greater the severity of health behavior. According to the procedure of the applied test, the severity indicators in four categories of behavior were calculated, ie. proper eating habits, preventive behavior, positive attitudes and mental health practices. The overall rate of health behaviors was converted to sten scale, and the results obtained in accordance with the guidelines of the author of the test were interpreted as follows: 1-4 sten as low, 5-6 sten as average and 7-10 as high.

The collected materials underwent statistical elaboration, using Microsoft Office Excel 2010 spreadsheet and Statistica 10 programme. To test the significance of differences between the means- T-Student's test was used. The analyzes assumed as relevant the effects, for which the probability value was less than the accepted level of significance of 0.05 $(p<0.05)$. For assessment of the relationships between variables Pearson's correlation coefficient was applied.

\section{Analysis of results}

The average age of the researched women from the rural environment was 43 years old, while of those from the city - 48 years. Living environment differentiates the education of the respondents. In cities with more than 100 thousand population nearly $55 \%$ of women were higher education graduates and only $6.15 \%$ of them had a vocational degree. However, in towns up to 3 thousand inhabitants the highest percentage $(47.44 \%)$ consisted of persons with secondary education, higher MA degree was held by $32.05 \%$ and nearly $18 \%$ of respondents had vocational and lower degree of education.

Within the studied population, together with the increasing age, the level of education decreases. A slightly stronger correlation was observed among women in rural areas $(-0.396512)$ than those inhabiting large cities $(-0.289851)$.

The overall indicator of severity of health behaviors among women from large cities equated to 84.09, while in rural areas - it was at the level of 82.37. However, the difference was statistically insignificant. No statistically significant differences were also found for each category of health behaviors with the exception of Correct eating habits, of which a higher level was achieved by women from large cities, Table 1.

Table 1. Comparison of the analyzed indicators of health behaviors of the surveyed women- having regard to the living environment

\begin{tabular}{|l|l|l|c|c|c|}
\hline \multicolumn{1}{|c|}{ Health habits indicators } & women from rural areas $\bar{X}$ & Women from metropolitan areas $\bar{X}$ & $\mathrm{t}$ & $\mathrm{df}$ & $\mathrm{p}$ \\
\hline Overall indicator of behaviors & 82,37179 & 84,09231 & $-0,9936$ & 206 & 0,321579 \\
\hline Correct eating habits & 3,30128 & 3,60000 & $-2,9240$ & 206 & 0,003843 \\
\hline prophylactic behaviors & 3,47436 & 3,53718 & $-0,6428$ & 206 & 0,521050 \\
\hline positive mental attitudes & 3,56410 & 3,50513 & 0,6429 & 206 & 0,521015 \\
\hline health practices & 3,38889 & 3,37308 & 0,1772 & 206 & 0,859532 \\
\hline
\end{tabular}


Upon conversion to sten values (in accordance with the procedure adopted by the author's research tools), a general structure of an indicator of the severity of the health behaviors among the surveyed women was obtained, as illustrated on Figure 1. As many as $30 \%$ of participants received a low score, $45 \%$ obtained an average score, while only $25 \%$ - high one.

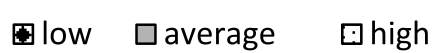

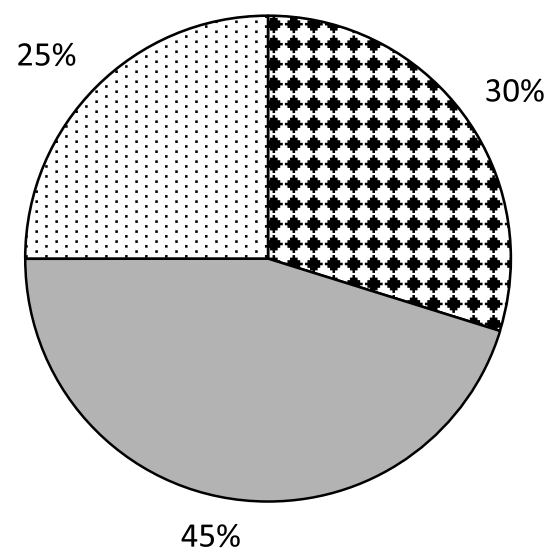

Figure 1. Level of the overall severity of the health behaviors among the surveyed women

The average value of the overall indicator of health behaviors of the respondents (83.23) is slightly lower than the average value reported by the author's research tools for adult Polish women (84.04) . When performing a detailed analysis of each category of behaviors (Figure 2) differences between them were disclosed. The largest of them (result below average) was found in case of a positive mental attitude and health practices.

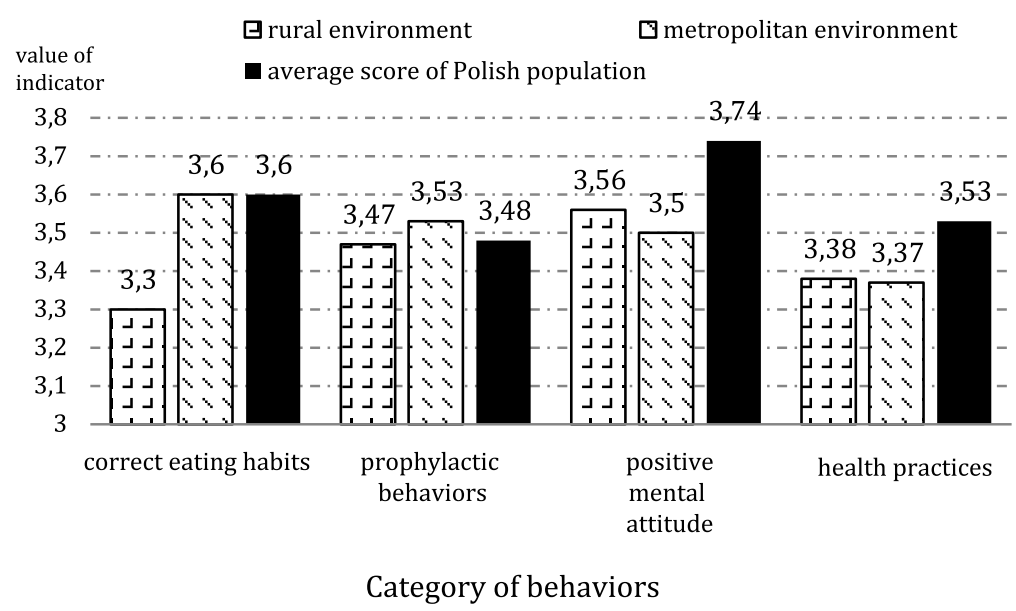

Figure 2. Second level of average values for each category of health behaviors examined in relation to the average performance of the Polish population of women

For women from the metropolitan environment, it was found that with an increasing age the level of overall indicator of health behavior tends to increase $(r=0.278214)$. Positive correlation with age also occurred in the case of such categories of behaviors as correct eating habits $(\mathrm{r}=0.238875)$ and prophylactic behaviors $(\mathrm{r}=0.237087)$. No correlations between age and health behavior in women from the towns of up to 3 thousand inhabitants were noted.

\section{Discussion}

Many factors influence the formation of healthy behaviors. Green and Kreuter (1991) mention three: a) aptitude - related to knowledge, beliefs, attitudes of people, b) allowing - allowing certain health policy choices and actions of people, c) strengthening - moral standards, local traditions, social acceptance of certain actions or behaviors or its absence, as well as socio-economic conditions in which man lives. 
Certainly, one may wonder to what extend may the rural environment hinder or facilitate the implementation of health behaviors. The fact is that in Poland the human lifespan is correlated to the size of the town in which one lives - the larger, the longer average life expectancy; moreover, rural inhabitants have limited access to specialized health care - they are hospitalized less often than urban inhabitants (Wojtyniak, Goryński 2008).

Research confirmed that groups with lower socio-economic status have a higher incidence of applying healthy practices (Ostrowska 1999). The substrate for the implementation of specific health behaviors are socio-cultural factors (Backett, Davison 1995) . They enforce adopting certain attitudes towards important community behaviors. Local traditions associated with lifestyle (eg. ways of spending free time) are not necessarily the health-related behaviors, but they can be considered as valuable and practiced as they constitute culture advantages of the region, promoted in the context of its economic potential.

Undoubtedly, place of residence determines certain attitudes, behaviors, habits in the field of prevention and health promotion. Despite the many programmes and activities of specialized institutions we might still encounter the inequalities in health and health behaviors.

Gacek (2011), in his study of health behaviors of perimenopausal aged women showed a wide variation of behavior depending on the place of residence. Women living in the city were characterized by higher consumption of alcoholic beverages, more frequent smoking, but also a higher level of participation in recreational physical activities, use of more effective ways of coping with work related stress.

In author's study, no statistically significant differences were noticed, since the studied set of behaviors included in one overall indicator of the severity of health behaviors, and not individual behaviors. Kózka et al. (2013) within the studies on postmenopausal women also showed no significant statistical differentiation in health behaviors dependent from one's place of residence. In the younger age groups-within similar studies using research tools applied in this author's study- also no relation between health behaviors and the place of residence was noted (Niedzielski et al.2008, Nowak, Barcicka 2013).

These results may be explained by the fact that the differences between a town and a countryside tend to blur. Migration of populations impair the traditionally understood image of the urban environment as well as the rural one. Technological advances in the field of transport communications and IT reduce the distance between these environments. Changes are taking place in the occupational structure of people living in rural areas. Subsequently, gradual decline in the share of people employed in agriculture. Non-agricultural sectors in rural areas continuously develop, including rural tourism and agritourism farms with recreation-related facilities. However, in spite of improvements on the educational level of the rural population it is still much lower than the level observed among the urban residents (Bański 2007).

The development of health education, education on healthy lifestyles is affected by the mass media, including primarily the Internet, which is an interactive source of information and space to acquire competencies in support of health. Access to the Internet is becoming wider and wider, a range of easily accessible lifestyle related content has been increasingly expanded (Nowak 2013).

It can be assumed that the use of popularizing thematic services on health, addressed to specific social groups, contributes to eliminating barriers, blurring the boundaries between communities of residence. Thus, technological support, mobile internet access, IT education seem to be the key, and forward-looking, highly efficient investment in the field of public health. It should be noted that in addition to open access to reliable content sometimes a more important seems to be a form of giving of information and the involvement to Internet users. The subjects (subscribers of advice on a health service) were willing to share their experience, comment on a variety of content related to health issues, but the level of their health behaviors did not differ significantly from the average values for the Polish population.

$\mathrm{n}$ rural areas, there are sometimes more chances for the implementation of a healthy lifestyle than in the highly urbanized metropolitan environment. The global trend of increasing numbers of people living in cities leads to questions of how is the life in the city healthy and how to build healthy urban environments (Galea et al. 2005). Concentration of population in the metropolitan centers of forces modern solutions. Certainly solutions in the field of infrastructure in Poland still differ from western standards, but to build the so-called. green infrastructure, creating space for recreational sports is a task worthy of attention. The health policies of developed countries see a lot of different investments in the development of friendly health of the population (Rydin et al. 2012). 


\section{Conclusions}

- As many as $30 \%$ of the survey participants achieved a low level of health behaviors, $45 \%$ - average, and only $25 \%$ - high which, due to the interest of a healthy lifestyle topics (manifested activity in the online health portal) can be considered unsatisfactory.

- There was no statistically significant difference in the level of ongoing health behaviors among women living in rural and metropolitan areas.

- Research shows that Internet thematic services which discuss a healthy lifestyle, are a chance to equalize disparities in health behaviors and, consequently, in health, and therefore should support initiatives to incite interest in hw ealth education through the mass media.

\section{References:}

1. Backett K.C., Davison C. (1995), Lifecourse and lifestyle: The social and cultural location of health behaviours, Social Science \& Medicine, Tom 40, Nr 5, s. 629-638.

2. Bański J. (2007), Przemiany funkcjonalno-przestrzenne terenów wiejskich - diagnoza, rekomendacje dla KPZK i dyskusja, Instytut Geografii i Przestrzennego Zagospodarowania PAN, Warszawa, s. 28-36.

3. Gacek M. (2011), Wybrane zachowania zdrowotne grupy kobiet $w$ środowisku wiejskim i miejskim $w$ świetle statusu socjoekonomicznego i stanu odżywienia, Problemy Higieny i Epidemiologii, Tom 92, Nr 2, s. 260-266.

4. Galea S., Freudenberg N., Vlahov D. (2005), Cities and population health, Social Science \& Medicine, Nr 60, s. 1017-1033.

5. Gniazdowski A. (1990), Zachowania zdrowotne, Instytut Medycyny Pracy, Łódź, s. 1-2.

6. Prochaska J.0. (2008), Multiple Health Behavior Research represents the future of preventive medicine, Preventive Medicine, $\mathrm{Nr}$ 46, s. 281-285.

7. Green L.W., Kreuter M.W. (1991), Health promotion planning: An educational and environmental approach. Mayfield Publishing Company, MountainView.

8. Juczyński Z. (2009), Narzędzia pomiaru w promocji i psychologii zdrowia, Pracownia testów psychologicznych, Warszawa.

9. Kózka M., Prażmowska B., Dziedzic M., Semczak M. (2013), Styl życia kobiet w okresie menopauzalnym - badania wstępne. Przegląd Medyczny Uniwersytetu Rzeszowskiego i Narodowego Instytutu Leków w Warszawie, Nr 4, s. 61-74.

10. Narodowy Program Zdrowia na lata 2007-2015 (2007), Załącznik do Uchwały nr 90/2007 Rady Ministrów z dnia 15 maja 2007r. Warszawa.

11. Niedzielski A., Bogusz R., Humeniuk E. (2008), Poziom zachowań zdrowotnych wśród młodzieży ostatnich klas wiejskiej szkoły średniej, W: A. Bochniarz, J. Bogucki, A. Grabowiec (red.), Zdrowa szkoła zdrowy uczeń. Teoria i praktyka edukacji zdrowotnej. Wybrane zagadnienia.NeuroCentrum. Lublin, s. 155-161.

12. Nowak P.F. (2013), Interaktywna edukacja zdrowotna w środkach przekazu medialnego, W: I. Gembalczyk, B. Fedyn (red.), Edukacja zdrowotna. Dokonania, aktualności, perspektywy. PWSZ, Racibórz, s. 205-214.

13. Nowak P.F., Barcicka P. (2013), Wybrane zachowania zdrowotne gimnazjalistów ze środowiska wiejskiego i miejskiego, Polski Przegląd Nauk o Zdrowiu, Tom 31, Nr 1, s. 13-18.

14. Ostrowska A. (1999), Styl życia a zdrowie, Wyd. IFiS PAN, Warszawa.

15. Pisinger C., Toft U., Aadahl M., Glümer C., Jørgensen T. (2009) The relationship between lifestyle and selfreported health in a general population The Inter 99 study.PreventiveMedicine 49, 418-423

16. Rydin Y., Bleahu A., Davies M., Dávila J. D., Friel S., De Grandis G., Groce N., Hallal P.C., Hamilton I., Howden-Chapman P., Lai K-M., Lim C.J., Martins J., Osrin D., Ridley I., Scott I., Taylor M., Wilkinson P., Wilson J. (2012) Shaping cities for health: complexity and the planning of urban environments in the 21st century. Lancet; 379: 2079-108.

17. Wojtyniak B., Goryński P. (2008) Sytuacja zdrowotna ludności Polski. NIZP-PZH, Warszawa, 31-108.

18. Woynarowska B. (2008) Edukacja zdrowotna, PWN Warszawa.

19. Zdrowie 21. Zdrowie dla wszystkich w XXI wieku (2001) Światowa Organizacja Zdrowia, tłum. J. B. Karski Uniwersyteckie wydawnictwo Vesalius, Warszawa. 